\title{
Synthesis and Spectral Studies of Some Homo Dinuclear Lanthanide(III) Complexes of a Mesogenic Schiff Base
}

\author{
Prem Kumar Shrestha and Pawan Raj Shakya* \\ Department of Chemistry, Padma Kanya Multiple Campus, Tribhuvan University, Kathmandu, Nepal \\ * Corresponding author: E-mail: pawansh2003@yahoo.com \\ Tel.: +977-1-4218218
}

Received: 04-14-2021

\begin{abstract}
A mesogenic Schiff base, N,N'-di(4-decyloxysalicylidene)-1',8'-diamino-3',6'-dioxaoctane $\left(\mathrm{H}_{2} \mathrm{~L}\right)$ and a series of homo dinuclear lanthanide(III) complexes of the type $\left[\mathrm{Ln}_{2}\left(\mathrm{LH}_{2}\right)_{3}\left(\mathrm{NO}_{3}\right)_{4}\right]\left(\mathrm{NO}_{3}\right)_{2},(\mathrm{Ln}=\mathrm{La}, \mathrm{Pr}, \mathrm{Nd}, \mathrm{Sm}, \mathrm{Eu}, \mathrm{Gd}, \mathrm{Tb}, \mathrm{Dy}$, and Ho) were synthesized and characterized by elemental analysis, mass spectrometry, FTIR, and NMR spectral techniques. The IR and NMR spectral evidences imply bonding of a neutral bidentate $\mathrm{H}_{2} \mathrm{~L}$ species through two phenolate oxygen atoms in its zwitterionic form to $\mathrm{Ln}^{\mathrm{III}}$, rendering the overall geometry of the complexes as a seven-coordinate polyhedron - possibly distorted mono-capped octahedron. Differential scanning calorimetry (DSC) and polarizing optical microscopic (POM) studies reveal mesogenic properties (smectic-X, smectic-A and nematic mesophases) in the ligand over a wide range of temperature but none mesomorphism in the $\mathrm{Ln}^{\mathrm{III}}$ complexes synthesized under this study. Luminescence studies exhibit emissions of $\mathrm{H}_{2} \mathrm{~L}$ and $\mathrm{Tb}^{\mathrm{III}}$ complex.
\end{abstract}

Keywords: Mesogenic Schiff base; Ln ${ }^{\mathrm{III}}$ Complexes; Zwitterionic-coordination; Mono-capped octahedron; Luminescence

\section{Introduction}

Lanthanide(III) complexes have received much attention due to their potential scientific applications in design of various luminescent metallomesogens, ${ }^{1,2}$ chemosensors, ${ }^{1,3}$ and photoluminescence materials and devices. ${ }^{4}$ Schiff base ligands having $\mathrm{N}$ and/or $\mathrm{O}$ donor atoms may assemble coordination architectures in which the Ln ${ }^{\mathrm{III}}$ ions can promote Schiff base condensation. ${ }^{5}$ Mesomorphisms (an anisotropic liquid) in Schiff base ligands, may be obtained by their careful design in which the molecular order is in between the crystalline and isotropic liquid state. ${ }^{6}$ By incorporating $\mathrm{Ln}^{\mathrm{III}}$ ions into the mesogenic Schiff base, one can obtain useful metallomesogens for the design of emissive LCDs.

The mesogenic properties of the ligands may often be influenced by the nature of coordinated metal ions., ${ }^{7,8}$ A metallomesogen has the greater tendency to exhibit intermolecular dative coordination in solid state., ${ }^{7,9}$ The design of metallomesogens is rather difficult because of their high coordination numbers incompatible with the structural anisotropy, the basics for showing liquid crys- talline behavior. ${ }^{9}$ However, the columnar type of $\mathrm{Ln}^{\text {III }}$ ion containing metallomesogens was first synthesized by Piechocki et al., ${ }^{10}$ in 1985 followed by the first calamitic $\mathrm{Ln}^{\mathrm{III}}$ ion containing metallomesogens by Galyametdinov et al., ${ }^{11}$ in 1991. Lanthanide(III) complexes with high coordination number may be obtained by choice of nitrate as the counter-ion because it can coordinate in a bi-dentate fashion. In continuation of our earlier work on metallomesogens, ${ }^{12-17}$ we now report here synthesis and spectral studies of a mesogenic Schiff base (having terminal alkoxy chain next to benzene ring) and of some homo dinuclear $\mathrm{Ln}^{\mathrm{III}}$ complexes.

\section{Experimental}

\section{1. Starting Materials}

All the required reagents of analytical grade (AR) were obtained from commercial sources and used without further purification; 1-bromodecane, 2,4-dihydroxybenzaldehyde and 1,8-diamino-3,6-dioxaoctane are from Sigma-Aldrich, USA; all the $\mathrm{Ln}\left(\mathrm{NO}_{3}\right)_{3} \mathrm{xH}_{2} \mathrm{O}$ salts are 
from Indian Rare Earths Ltd. and $\mathrm{KI}$ and $\mathrm{KHCO}_{3}$ are from Merck. The organic solvents obtained from commercial vendors were dried using standard methods. ${ }^{18}$

\section{2. Synthesis}

Experimental details given in Scheme 1 show synthesis of $N, N^{\prime}$-di-(4-decyloxysalicylidene)-1',8'-diamino-3',6'-dioxaoctane $\left(\mathrm{H}_{2} \mathrm{~L}\right), 2$, by a two-step process, alkylation of 2,4-dihydroxybenzaldehyde with 1-bromodecane followed by condensation with 1,8-diamino-3,6-dioxaoctane. The $\mathrm{Ln}^{\mathrm{III}}$ complexes, $\left[\mathrm{Ln}_{2}\left(\mathrm{LH}_{2}\right)_{3}\left(\mathrm{NO}_{3}\right)_{4}\right]\left(\mathrm{NO}_{3}\right)_{2}(\mathrm{Ln}$ $=\mathrm{La}, \mathrm{Pr}, \mathrm{Nd}, \mathrm{Sm}, \mathrm{Eu}, \mathrm{Gd}, \mathrm{Tb}, \mathrm{Dy}$, and Ho), 3, were synthesized by reacting the $\mathrm{H}_{2} \mathrm{~L}$ and appropriate metal nitrate in solution state at room temperature.

\section{2. 1. Preparation of 4-decyloxysalicylaldehyde, 1}

Equimolar amounts of 2,4-dihydroxybenzaldehyde (50 mmol, 6.91 g) and 1-bromodecane (50 mmol, $10.4 \mathrm{~mL}$ ) were mixed with $100 \mathrm{~mL}$ of dry acetone and added potassium bicarbonate $(55 \mathrm{mmol}, 5.51 \mathrm{~g})$. The reaction mixture was refluxed for $30 \mathrm{~h}$ in the presence of KI (0.1-0.2 g) as a catalyst. Insoluble solids were removed through hot fil- tration and subsequently, the filtrate was made neutral by adding $6 \mathrm{~N}$ hydrochloric acid little at a time and extracted the product twice with $100 \mathrm{~mL}$ portions of $\mathrm{CHCl}_{3}$. A straw-yellow solid was obtained upon concentration of the chloroform extracts which was purified by column chromatography over $\mathrm{SiO}_{2}$ by eluting first with $\mathrm{n}$-hexane and then with a mixture of $\mathrm{n}$-hexane and chloroform (v/v, 1/1). The product, 4-decyloxysalicylaldehyde (1) was obtained in the form of a white solid upon evaporation of this purified extract; yield: 68\% (9.47 g).

\section{2. 2. Synthesis of $N, N^{\prime}-d i-(4-$ decyloxysalicylidene)-1',8'-diamino-3',6'- dioxaoctane $\left(\mathrm{H}_{2} \mathrm{~L}\right), 2$}

A mixture of absolute ethanolic solutions of 4-decyloxysalicylaldehyde, $\mathbf{1},(8.34 \mathrm{~g}, 30 \mathrm{mmol}$ in $50 \mathrm{~mL})$ and 1,8-diamino-3,6-dioxaoctane (2.22 g, $15 \mathrm{mmol}$ in $15 \mathrm{~mL}$ ) was refluxing together for $1.5 \mathrm{~h}$ in the presence of a few drops of glacial acetic acid. Yellow colored solid, 2, was obtained after the resulting mixture left overnight which was filtered off under suction, thoroughly washed with cold ethanol and dried at room temperature. Yield: $74 \%$ (7.43 g), m.p. $165^{\circ} \mathrm{C}$. Anal. Calcd for $\mathrm{C}_{40} \mathrm{H}_{64} \mathrm{~N}_{2} \mathrm{O}_{6}(\%)$ : C, 71.82; H; 8.64; N, 4.19.

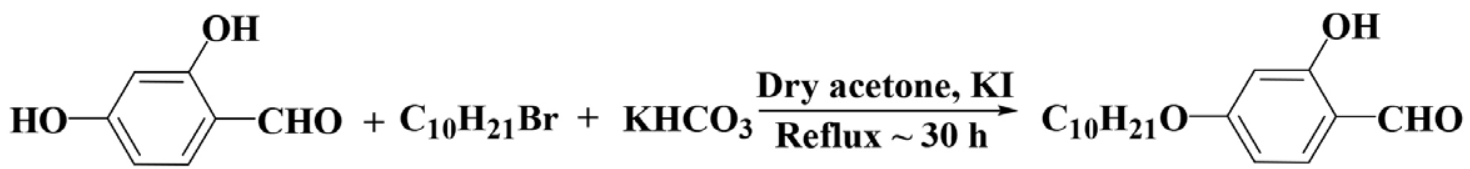

(1)

$+\mathrm{KBr}+\mathrm{H}_{2} \mathrm{O}+\mathrm{CO}_{2}$
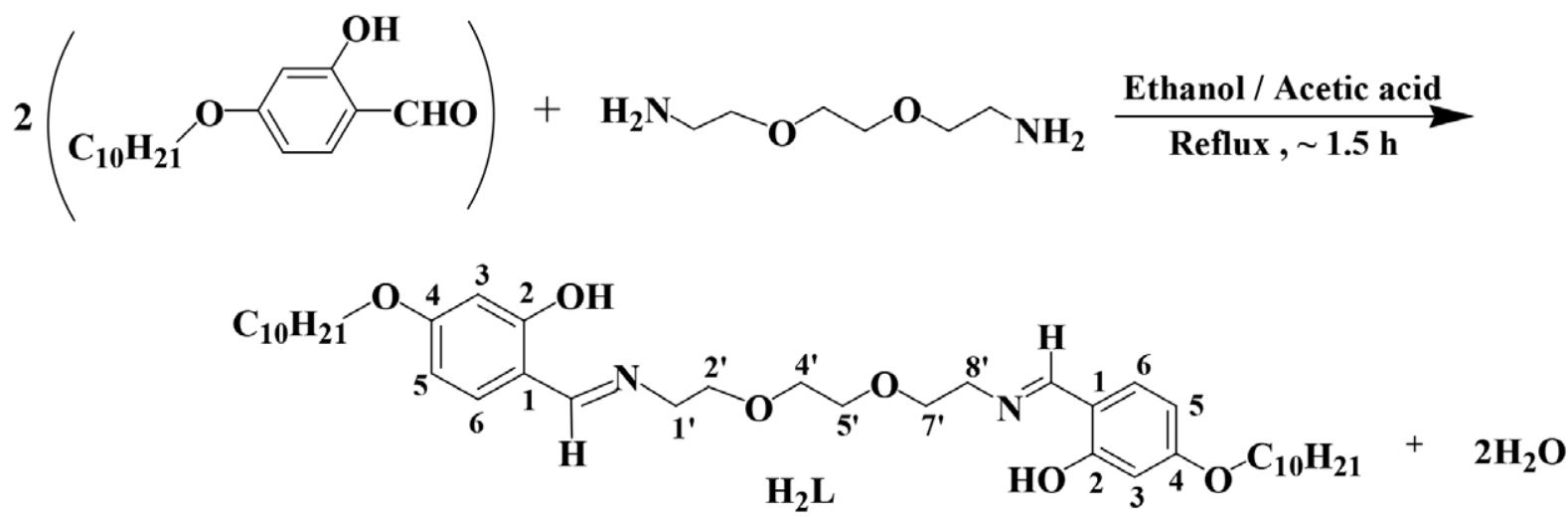

(2)

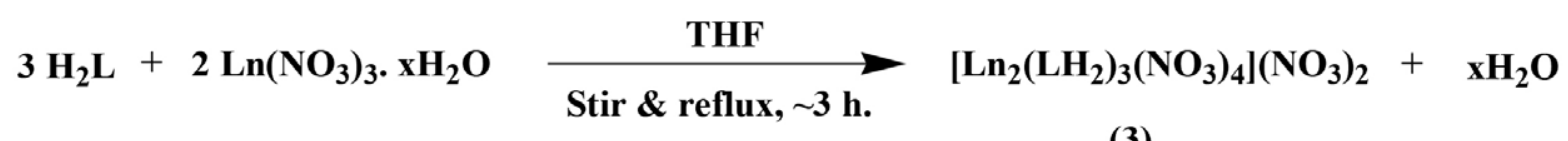

(3)

\section{Where,}

\section{Ln $=$ La, Pr, Nd, Sm, Eu, Gd, Tb, Dy and Ho}

Scheme 1. Reaction steps involved in the synthesis of 4-decyloxysalicylaldehyde, 1; $N, N^{\prime}$-di-(4-decyloxysalicylidene)-1',8'-diamino-3',6'-dioxaoctane $\left(\mathrm{H}_{2} \mathrm{~L}\right), 2$, and $\mathrm{Ln}^{\mathrm{III}}$ complexes, 3 . 
Found (\%): C, 71.85; H, 9.65; N, 4.21. ${ }^{1} \mathrm{H}$ NMR $(300 \mathrm{MHz}$; DMSO- $\left.d_{6} ; J(\mathrm{~Hz}), \mathrm{ppm}\right)$ (Figure S1) $\delta=0.85(\mathrm{t}, J=5.7,3 \mathrm{H}$, $\left.-\mathrm{CH}_{3}\right), 1.73-1.26\left(\mathrm{~m}, 16 \mathrm{H},-\left(\mathrm{CH}_{2}\right)_{8}-\right), 3.51(\mathrm{t}, J=6.6,2 \mathrm{H}$, $\left.-\mathrm{NCH}_{2}\right), 3.96\left(\mathrm{t}, J=6.3,2 \mathrm{H},-\mathrm{OCH}_{2}\right), 6.28(\mathrm{~d}, J=11.4,1 \mathrm{H}$, $\mathrm{Ar}-\mathrm{H}), 6.33$ (s, 1H, Ar-H), 7.19 (d, J= 8.7, 1H, Ar-H), 8.32 (s, $1 \mathrm{H},-\mathrm{N}=\mathrm{CH}), 13.80$ (s, br, $1 \mathrm{H}, \mathrm{Ph}-\mathrm{OH}) ;{ }^{13} \mathrm{C}\left\{{ }^{1} \mathrm{H}\right\} \mathrm{NMR}$ : $\left(75.45 \mathrm{MHz}\right.$; DMSO- $d_{6}$; ppm) (Figure S2) $\delta=165.39,163.82$, $162.36,132.45,111.70,105.56,101.40,67.27$; FAB Mass (m/e, fragment, \% intensity): the molecular ion as base peak (668, $\left.\mathrm{M}^{+}, 100\right)$ generates simultaneously four fragments, $\mathrm{M}_{1}-\mathrm{M}_{4}$; $\mathrm{M}_{1}: 349, \mathrm{C}_{10} \mathrm{H}_{21} \mathrm{OC}_{6} \mathrm{H}_{3}(\mathrm{OH}) \mathrm{CH}=\mathrm{NC}_{2} \mathrm{H}_{4} \mathrm{OCH}_{2} \mathrm{CH}_{2}{ }^{+}, 28 \%$; $\mathrm{M}_{2}: 321, \mathrm{C}_{10} \mathrm{H}_{21} \mathrm{OC}_{6} \mathrm{H}_{3}(\mathrm{OH}) \mathrm{CH}=\mathrm{NCH}_{2} \mathrm{CH}_{2} \mathrm{O}^{+}, 25 \% ; \mathrm{M}_{3}$ : $305, \mathrm{C}_{10} \mathrm{H}_{21} \mathrm{OC}_{6} \mathrm{H}_{3}(\mathrm{OH}) \mathrm{CH}=\mathrm{NCH}_{2} \mathrm{CH}_{2}^{+}, 35 \% ; \mathrm{M}_{4}$ (generated from $\left.\mathrm{M}_{3}\right): 164,(\mathrm{OH}) \mathrm{C}_{6} \mathrm{H}_{3}(\mathrm{OH}) \mathrm{CH}=\mathrm{NCH}_{2} \mathrm{CH}_{2}{ }^{+}, 25 \%$; IR $\left(\mathrm{cm}^{-1}, \mathrm{KBr}\right.$ disk): $3458(v-\mathrm{OH}), 1628(v-\mathrm{C}=\mathrm{N}), 1150$ $\left(v-\mathrm{C}_{\mathrm{ph}}-\mathrm{O}\right)$.

\section{2. 3. Synthesis of $\mathrm{La}^{\mathrm{III}}$ Complex, $\left[\mathrm{Ln}_{2}\left(\mathrm{LH}_{2}\right)_{3}\left(\mathrm{NO}_{3}\right)_{4}\right]\left(\mathrm{NO}_{3}\right)_{2}, 3$}

Mixing of THF solutions of $\mathrm{H}_{2} \mathrm{~L}(2.01 \mathrm{~g}, 3.0 \mathrm{mmol}$ in $30 \mathrm{~mL})$ and of $\mathrm{La}\left(\mathrm{NO}_{3}\right)_{3} 6 \mathrm{H}_{2} \mathrm{O}(0.87 \mathrm{~g}, 2.0 \mathrm{mmol}$ in 20 $\mathrm{mL}$ ) under magnetic stirring turned the resultant solution cloudy after $15 \mathrm{~min}$. A light yellow colored solid separated upon continuous stirring for $3 \mathrm{~h}$ at room temperature was filtered off under suction, washed repeatedly with cold methanol, and dried over fused $\mathrm{CaCl}_{2}$ in a desiccator. Yield: $65 \%$ (1.73 g) as yellow solid; m.p. $245^{\circ} \mathrm{C}$ (decompose); Anal. Calcd for $\mathrm{La}_{2} \mathrm{C}_{120} \mathrm{H}_{192} \mathrm{~N}_{12} \mathrm{O}_{36}$ (\%): C, 54.25; H, 7.28; N, 6.33; La, 10.46; Found (\%): C, 54.30; H, 7.30; N, 6.37 and La, $10.51 ;{ }^{1} \mathrm{H}$ NMR $\left(300 \mathrm{MHz}\right.$; DMSO- $d_{6} ; J(\mathrm{~Hz})$, ppm) (Figure S3) $\delta=0.88\left(\mathrm{t}, J=5.4,3 \mathrm{H},-\mathrm{CH}_{3}\right), 1.71-1.29$ $\left(\mathrm{m}, 16 \mathrm{H},-\left(\mathrm{CH}_{2}\right)_{8}{ }^{-}\right), 3.54\left(\mathrm{t}, J=6.3,2 \mathrm{H},-\mathrm{NCH}_{2}\right), 3.98(\mathrm{t}, J$ $\left.=6.3,2 \mathrm{H},-\mathrm{OCH}_{2}\right), 6.34(\mathrm{~d}, J=6.6,1 \mathrm{H}, \mathrm{Ar}-\mathrm{H}), 6.36(\mathrm{~s}, 1 \mathrm{H}$, $\mathrm{Ar}-\mathrm{H}), 7.22(\mathrm{~d}, J=8.7,1 \mathrm{H}, \mathrm{Ar}-\mathrm{H}), 8.36(\mathrm{~s}, 1 \mathrm{H},-\mathrm{N}=\mathrm{CH})$, 9.27 (s, br, $\left.1 \mathrm{H},-\mathrm{N}^{+} \mathrm{H}\right) ;{ }^{13} \mathrm{C}\left\{{ }^{1} \mathrm{H}\right\} \mathrm{NMR}$ : $(75.45 \mathrm{MHz}$; DMSO- $d_{6}$; ppm) (Figure S4) $\delta=166.07,162.61,164.02$, 132.75, 111.67, 105.64, 101.56, 67.35; IR ( $\mathrm{cm}^{-1}, \mathrm{KBr}$ disk): $3046\left(v-\mathrm{N}^{+} \mathrm{H}\right), 1658(v-\mathrm{C}=\mathrm{N}), 1124\left(v-\mathrm{C}_{\mathrm{ph}}-\mathrm{O}\right)$.

All the other $\mathrm{Ln}^{\mathrm{III}}$ complexes $(\mathrm{Ln}=\mathrm{Pr}, \mathrm{Nd}, \mathrm{Sm}, \mathrm{Eu}$, $\mathrm{Gd}, \mathrm{Tb}, \mathrm{Dy}$, and $\mathrm{Ho}$ ) were synthesized in an analogous way by using the appropriate hydrated salt of $\mathrm{Ln}^{\mathrm{III}}$ nitrate; the physical properties and the analytical data of all the complexes are given in Table 1 while the NMR data of the ligand $\left(\mathrm{H}_{2} \mathrm{~L}\right)$ and the $\mathrm{La}^{\mathrm{III}}$ complex are presented as supplementary data. Infrared spectral data of the ligand and complexes are given in Table 2; the data of two representative complexes are given below: $\left[\mathrm{Gd}_{2}\left(\mathrm{LH}_{2}\right)_{3}\left(\mathrm{NO}_{3}\right)_{4}\right]\left(\mathrm{NO}_{3}\right)_{2}$ : IR $\left(\mathrm{cm}^{-1}, \mathrm{KBr}\right.$ disk): $3026\left(v-\mathrm{N}^{+} \mathrm{H}\right), 1654(v-\mathrm{C}=\mathrm{N}), 1124$ $\left(v-\mathrm{C}_{\mathrm{ph}}-\mathrm{O}\right) ;\left[\mathrm{Ho}_{2}\left(\mathrm{LH}_{2}\right)_{3}\left(\mathrm{NO}_{3}\right)_{4}\right]\left(\mathrm{NO}_{3}\right)_{2}: \mathrm{IR}\left(\mathrm{cm}^{-1}, \mathrm{KBr}\right.$ disk): $3038\left(v-\mathrm{N}^{+} \mathrm{H}\right), 1654(v-\mathrm{C}=\mathrm{N}), 1124\left(v-\mathrm{C}_{\mathrm{ph}}-\mathrm{O}\right)$.

\section{3. Physical Measurements}

The $\mathrm{Ln}^{\mathrm{III}}$ ions in the complexes were determined complexometrically by titrating against the standard EDTA solution using xylenol orange as a metal ion indicator. The elemental contents $(\mathrm{C}, \mathrm{H}$ and $\mathrm{N})$ were analyzed on an Exeter Analyzer, Model CE-440 CHN. Bruker Av III HD (DRX) $300 \mathrm{MHz}$ FT-NMR multinuclear spectrometer was used to record the ${ }^{1} \mathrm{H}$ and ${ }^{13} \mathrm{C}$ NMR spectra while Bruker IFS66 FTIR spectrometer recorded IR spectra within the $4000-400 \mathrm{~cm}^{-1}$ region using $\mathrm{KBr}$ pellets. Mass spectra were recorded on JEOL SX-102 FAB mass spectrometer. UV-vis spectra were recorded on Shimadzu spectrophotometer, model Pharmaspec-UV 1700. The molar conductance of the complexes was determined in $10^{-3} \mathrm{M}$ solutions on a digital conductivity meter (Model alpha-06, ESICO International) using a commercial conductivity 'dip cell' of cell constant, 1.03. Magnetic susceptibility measurements were made at room temperature on a Cahn-Faraday balance using $\mathrm{Hg}\left[\mathrm{Co}(\mathrm{NCS})_{4}\right]$ as the calibrant. Mesophases were identified by the optical textures using an Olympus BX60 Polarizing Optical Microscope (POM) equipped with a Linkam THMS600 hot stage and a Linkam TMS93 programmable temperature controller (heating and cooling rates of $2{ }^{\circ} \mathrm{C} / \mathrm{min}$ ). Differential Scanning Calorimetry (DSC) studies were made on a Mettler-Toledo DSC822e module (scan rate $10{ }^{\circ} \mathrm{C} / \mathrm{min}$ under a helium flow, aluminum cups). Fluorescence measurements were recorded at room temperature in a mixed solvent of $\mathrm{CHCl}_{3} / \mathrm{DMSO}$ solutions $\left(3: 1 \mathrm{v} / \mathrm{v} ; 10^{-4} \mathrm{~mol} \mathrm{~L}^{-1} ; \lambda_{\text {ex }}, 380 \mathrm{~nm}\right)$ on a Perkin Elmer LS-45 luminescence spectrometer $(10 \mathrm{~nm}$ slit width on both excitation and emission).

\section{Results and Discussion}

\section{1. Properties of the Complexes}

The analytical data on elemental analyses, general behavior and some important physical properties of the $\mathrm{Ln}^{\mathrm{III}}$ complexes are given in Table 1 . The $\mathrm{Ln}^{\mathrm{III}}$ complexes synthesized under the study are of the type $\left[\operatorname{Ln}_{2}\left(\mathrm{LH}_{2}\right)_{3}\left(\mathrm{NO}_{3}\right)_{4}\right]$ $\left(\mathrm{NO}_{3}\right)_{2}$ indicating 2:3 metal to ligand stoichiometry with nitrate groups present both outside and within the coordination sphere. The molar conductivity measurements in $10^{-3} \mathrm{M}$ DMF solutions $\left(110-125 \Omega^{-1} \mathrm{~cm}^{2} \mathrm{~mol}^{-1}\right)$ of the $\mathrm{Ln}^{\mathrm{III}}$ complexes imply 2:1 electrolytic behavior. ${ }^{19}$

\section{2. FAB-mass Spectral Study of $\mathbf{H}_{2} \mathrm{~L}$}

The formation of the Schiff base ligand $\left(\mathrm{H}_{2} \mathrm{~L}\right)$, in addition to the IR and NMR spectral techniques to be discussed later, was further confirmed by the FAB mass spectrum. The molecular ion peak as well as base peak that corresponds to the $m / e$ value of 668 , matches with the molecular weight of the ligand (668.95) having the molecular formula, $\mathrm{C}_{40} \mathrm{H}_{64} \mathrm{~N}_{2} \mathrm{O}_{6}$. The $100 \%$ intensity of the molecular ion peak as the base peak is as expected for the molecule on the basis of its predominant aromatic character; the major fragment peaks $(m / e=349$, $321,305,164)$ are due to $\mathrm{C}_{10} \mathrm{H}_{21} \mathrm{OC}_{6} \mathrm{H}_{3}(\mathrm{OH}) \mathrm{CH}=\mathrm{N}$ - 
Table 1. General and analytical data of $\mathrm{H}_{2} \mathrm{~L}$ and of $\mathrm{Ln}^{\mathrm{III}}$ metal complexes.

\begin{tabular}{|c|c|c|c|c|c|c|c|}
\hline \multirow{2}{*}{$\begin{array}{l}\mathrm{H}_{2} \mathrm{~L} / \text { complex formula } \\
\text { weight (empirical formula) }\end{array}$} & \multirow[t]{2}{*}{ Colour, yield } & \multirow[t]{2}{*}{ m.p. $\left({ }^{\circ} \mathrm{C}\right)$} & \multicolumn{4}{|c|}{ Found (Calcd.)\% } & \multirow{2}{*}{$\begin{array}{c}\mu_{\text {eff }}(\text { van Vleck }) \\
\text { value, B.M. }\end{array}$} \\
\hline & & & $\mathrm{C}$ & $\mathbf{H}$ & $\mathbf{N}$ & $\mathbf{M}$ & \\
\hline $\mathrm{H}_{2} \mathrm{~L}$ & Yellow, 74\% & 165 & 71.85 & 9.65 & 4.21 & - & - \\
\hline $668.95\left(\mathrm{C}_{40} \mathrm{H}_{64} \mathrm{~N}_{2} \mathrm{O}_{6}\right)$ & & & $(71.82)$ & $(9.64)$ & $(4.19)$ & & \\
\hline$\left[\mathrm{La}_{2}\left(\mathrm{LH}_{2}\right)_{3}\left(\mathrm{NO}_{3}\right)_{4}\right]\left(\mathrm{NO}_{3}\right)_{2}$ & Light yellow, 65\% & $245^{\mathrm{d}}$ & 54.30 & 7.30 & 6.37 & 10.51 & Diamag. \\
\hline $2656.68\left(\mathrm{La}_{2} \mathrm{C}_{120} \mathrm{H}_{192} \mathrm{~N}_{12} \mathrm{O}_{36}\right)$ & & & $(54.25)$ & $(7.28)$ & $(6.33)$ & $(10.46)$ & \\
\hline$\left[\mathrm{Pr}_{2}\left(\mathrm{LH}_{2}\right)_{3}\left(\mathrm{NO}_{3}\right)_{4}\right]\left(\mathrm{NO}_{3}\right)_{2}$ & Light yellow, 66\% & $242^{\mathrm{d}}$ & 54.15 & 7.28 & 6.38 & 10.66 & 3.90 \\
\hline $2660.69\left(\mathrm{Pr}_{2} \mathrm{C}_{120} \mathrm{H}_{192} \mathrm{~N}_{12} \mathrm{O}_{36}\right)$ & & & $(54.12)$ & $(7.27)$ & $(6.32)$ & $(10.59)$ & $(3.40-3.60)$ \\
\hline$\left[\mathrm{Nd}_{2}\left(\mathrm{LH}_{2}\right)_{3}\left(\mathrm{NO}_{3}\right)_{4}\right]\left(\mathrm{NO}_{3}\right)_{2}$ & Light yellow, $72 \%$ & $238^{\mathrm{d}}$ & 54.10 & 7.28 & 6.28 & 10.90 & 3.94 \\
\hline $2667.35\left(\mathrm{Nd}_{2} \mathrm{C}_{120} \mathrm{H}_{192} \mathrm{~N}_{12} \mathrm{O}_{36}\right)$ & & & $(54.03)$ & $(7.26)$ & $(6.30)$ & $(10.82)$ & $(3.50-3.60)$ \\
\hline$\left[\mathrm{Sm}_{2}\left(\mathrm{LH}_{2}\right)_{3}\left(\mathrm{NO}_{3}\right)_{4}\right]\left(\mathrm{NO}_{3}\right)_{2}$ & Light yellow, 69\% & $240^{\mathrm{d}}$ & 53.82 & 7.26 & 6.30 & 11.30 & 1.87 \\
\hline 2679.59( $\left.\mathrm{Sm}_{2} \mathrm{C}_{120} \mathrm{H}_{192} \mathrm{~N}_{12} \mathrm{O}_{36}\right)$ & & & $(53.79)$ & $(7.22)$ & $(6.27)$ & $(11.22)$ & $(1.50-1.60)$ \\
\hline$\left[\mathrm{Eu}_{2}\left(\mathrm{LH}_{2}\right)_{3}\left(\mathrm{NO}_{3}\right)_{4}\right]\left(\mathrm{NO}_{3}\right)_{2}$ & Light yellow, 74\% & $255^{\mathrm{d}}$ & 53.75 & 7.23 & 6.32 & 11.37 & 4.56 \\
\hline $2682.80\left(\mathrm{Eu}_{2} \mathrm{C}_{120} \mathrm{H}_{192} \mathrm{~N}_{12} \mathrm{O}_{36}\right)$ & & & $(53.72)$ & $(7.21)$ & $(6.27)$ & $(11.33)$ & $(3.40-3.60)$ \\
\hline$\left[\mathrm{Gd}_{2}\left(\mathrm{LH}_{2}\right)_{3}\left(\mathrm{NO}_{3}\right)_{4}\right]\left(\mathrm{NO}_{3}\right)_{2}$ & Light yellow, 70\% & $258^{\mathrm{d}}$ & 53.49 & 7.23 & 6.29 & 11.71 & 10.84 \\
\hline 2693.37 $\left(\mathrm{Gd}_{2} \mathrm{C}_{120} \mathrm{H}_{192} \mathrm{~N}_{12} \mathrm{O}_{36}\right)$ & & & $(53.51)$ & $(7.19)$ & $(6.24)$ & $(11.68)$ & $(7.80-8.00)$ \\
\hline$\left[\mathrm{Tb}_{2}\left(\mathrm{LH}_{2}\right)_{3}\left(\mathrm{NO}_{3}\right)_{4}\right]\left(\mathrm{NO}_{3}\right)_{2}$ & Light yellow, 67\% & $260^{\mathrm{d}}$ & 53.47 & 7.21 & 6.28 & 11.86 & 11.84 \\
\hline $2696.72\left(\mathrm{~Tb}_{2} \mathrm{C}_{120} \mathrm{H}_{192} \mathrm{~N}_{12} \mathrm{O}_{36}\right)$ & & & $(53.45)$ & $(7.18)$ & $(6.23)$ & $(11.79)$ & $(9.40-9.60)$ \\
\hline$\left[\mathrm{Dy}_{2}\left(\mathrm{LH}_{2}\right)_{3}\left(\mathrm{NO}_{3}\right)_{4}\right]\left(\mathrm{NO}_{3}\right)_{2}$ & Light yellow, 70\% & $257^{\mathrm{d}}$ & 53.35 & 7.20 & 6.27 & 12.09 & 12.47 \\
\hline $2703.87\left(\mathrm{Dy}_{2} \mathrm{C}_{120} \mathrm{H}_{192} \mathrm{~N}_{12} \mathrm{O}_{36}\right)$ & & & $(53.30)$ & $(7.16)$ & $(6.22)$ & $(12.02)$ & $(10.40-10.50)$ \\
\hline$\left[\mathrm{Ho}_{2}\left(\mathrm{LH}_{2}\right)_{3}\left(\mathrm{NO}_{3}\right)_{4}\right]\left(\mathrm{NO}_{3}\right)_{2}$ & Light Yellow, 68\% & $258^{\mathrm{d}}$ & 53.22 & 7.19 & 6.26 & 12.25 & 14.36 \\
\hline $2608.73\left(\mathrm{Ho}_{2} \mathrm{C}_{120} \mathrm{H}_{192} \mathrm{~N}_{12} \mathrm{O}_{36}\right)$ & & & $(53.21)$ & $(7.14)$ & $(6.21)$ & $(12.18)$ & $(10.30-10.50)$ \\
\hline
\end{tabular}

$\mathrm{d}=$ decomposition

$\mathrm{C}_{2} \mathrm{H}_{4} \mathrm{OCH}_{2} \mathrm{CH}_{2}{ }^{+}, \mathrm{C}_{10} \mathrm{H}_{21} \mathrm{OC}_{6} \mathrm{H}_{3}(\mathrm{OH}) \mathrm{CH}=\mathrm{NCH}_{2} \mathrm{CH}_{2} \mathrm{O}^{+}$, $\mathrm{C}_{10} \mathrm{H}_{21} \mathrm{OC}_{6} \mathrm{H}_{3}(\mathrm{OH}) \mathrm{CH}=\mathrm{NCH}_{2} \mathrm{CH}_{2}{ }^{+}$, and $(\mathrm{OH}) \mathrm{C}_{6} \mathrm{H}_{3}(\mathrm{OH})$ $\mathrm{CH}=\mathrm{NCH}_{2} \mathrm{CH}_{2}{ }^{+}$species respectively.

\section{3. IR Spectral Studies}

The important infrared spectral data of $\mathrm{H}_{2} \mathrm{~L}$ and its $\mathrm{Ln}^{\mathrm{III}}$ complexes are presented in Table 2 .

The broad absorption, centered at $3458 \mathrm{~cm}^{-1}$ and characteristic of $v(\mathrm{O}-\mathrm{H})_{\text {phenolic }}{ }^{20}$ involving considerable $\mathrm{H}$-bonding, disappears in spectra of the complexes due to shifting of the phenolic proton to the azomethine nitrogen, resulting in formation of the zwitterion. The weak/ medium intensity bands of the $\mathrm{H}_{2} \mathrm{~L}$ centered at $1150 \mathrm{~cm}^{-1}$ are assigned to $v(\mathrm{C}-\mathrm{O})_{\text {phenolic }}$. The strong intensity band appearing at $1628 \mathrm{~cm}^{-1}$, which is assignable $\mathrm{e}^{21}$ to $v(\mathrm{C}=\mathrm{N})$ of azomethine, undergoes a hypsochromic shift in all the complexes on account of zwitterion formation. Thus, the complexation of the $\mathrm{H}_{2} \mathrm{~L}$ to $\mathrm{Ln}^{\mathrm{III}}$ results in migration of phenolic protons onto the two uncoordinated imino nitrogen atoms, which then are intramolecularly hydrogen bonded to metal-bound phenolate oxygen atoms to give the zwitterionic structure, $\mathrm{N}^{+}-\mathrm{H} \cdots \mathrm{O}^{-}$. Such zwitterionic behavior is in consistent with the study of Binnemans et al.,22 who also reported similar observation for acyclic Schiff base lanthanide complexes. The band frequencies of $v(\mathrm{C}=\mathrm{N})$ shifting to higher wave numbers upon complexation, also provide further evidence implying the presence of the $\mathrm{C}-\mathrm{N}^{+}$and the non-involvement of nitrogen in complex formation..$^{23}$ Further, the present complexes are

Table 2. IR Spectral data ${ }^{*}\left(\mathrm{~cm}^{-1}\right)$ of $\mathrm{H}_{2} \mathrm{~L}$ and of $\mathrm{Ln}^{\text {III }}$ metal complexes

\begin{tabular}{|c|c|c|c|c|c|c|c|c|c|}
\hline $\mathrm{H}_{2} \mathrm{~L} /$ Complexes & $\begin{array}{c}v(\mathrm{O}-\mathrm{H}) \\
\text { phenol }\end{array}$ & $\begin{array}{c}v \\
\left(\mathrm{~N}^{+} \mathrm{H}\right)\end{array}$ & $v(\mathrm{C}=\mathrm{N})$ & $\begin{array}{c}v(\mathrm{C}-\mathrm{O}) \\
\text { phenolic }\end{array}$ & $v_{5}$ & Ionic & $\begin{array}{c}v\left(\mathrm{NO}_{3}\right) \\
v_{1}\end{array}$ & $v_{2}$ & $v_{5}-v_{1}$ \\
\hline $\mathrm{H}_{2} \mathrm{~L}$ & $3458 \mathrm{~b}$ & - & $1628 \mathrm{~s}$ & $1150 \mathrm{~m}$ & - & - & - & - & - \\
\hline$\left[\mathrm{La}_{2}\left(\mathrm{LH}_{2}\right)_{3}\left(\mathrm{NO}_{3}\right)_{4}\right]\left(\mathrm{NO}_{3}\right)_{2}$ & - & $3046 w$ & 1656 & 1124 & 1470 & 1386 & 1290 & 794 & 180 \\
\hline$\left[\mathrm{Pr}_{2}\left(\mathrm{LH}_{2}\right)_{3}\left(\mathrm{NO}_{3}\right)_{4}\right]\left(\mathrm{NO}_{3}\right)_{2}$ & - & 3042 & 1654 & 1118 & 1469 & 1386 & 1294 & 794 & 175 \\
\hline$\left[\mathrm{Nd}_{2}\left(\mathrm{LH}_{2}\right)_{3}\left(\mathrm{NO}_{3}\right)_{4}\right]\left(\mathrm{NO}_{3}\right)_{2}$ & - & 3040 & 1654 & 1126 & 1470 & 1380 & 1292 & 791 & 178 \\
\hline$\left[\mathrm{Sm}_{2}\left(\mathrm{LH}_{2}\right)_{3}\left(\mathrm{NO}_{3}\right)_{4}\right]\left(\mathrm{NO}_{3}\right)_{2}$ & - & 3042 & 1654 & 1124 & 1470 & 1382 & 1292 & 792 & 180 \\
\hline$\left[\mathrm{Eu}_{2}\left(\mathrm{LH}_{2}\right)_{3}\left(\mathrm{NO}_{3}\right)_{4}\right]\left(\mathrm{NO}_{3}\right)_{2}$ & - & 3030 & 1654 & 1124 & 1468 & 1381 & 1288 & 793 & 181 \\
\hline$\left[\mathrm{Gd}_{2}\left(\mathrm{LH}_{2}\right)_{3}\left(\mathrm{NO}_{3}\right)_{4}\right]\left(\mathrm{NO}_{3}\right)_{2}$ & - & 3026 & 1654 & 1124 & 1467 & 1372 & 1290 & 791 & 177 \\
\hline$\left[\mathrm{Tb}_{2}\left(\mathrm{LH}_{2}\right)_{3}\left(\mathrm{NO}_{3}\right)_{4}\right]\left(\mathrm{NO}_{3}\right)_{2}$ & - & 3036 & 1654 & 1122 & 1471 & 1378 & 1294 & 792 & 177 \\
\hline$\left[\mathrm{Dy}_{2}\left(\mathrm{LH}_{2}\right)_{3}\left(\mathrm{NO}_{3}\right)_{4}\right]\left(\mathrm{NO}_{3}\right)_{2}$ & - & 3028 & 1654 & 1126 & 1472 & 1378 & 1292 & 793 & 180 \\
\hline$\left[\mathrm{Ho}_{2}\left(\mathrm{LH}_{2}\right)_{3}\left(\mathrm{NO}_{3}\right)_{4}\right]\left(\mathrm{NO}_{3}\right)_{2}$ & - & 3038 & 1654 & 1124 & 1470 & 1382 & 1290 & 794 & 180 \\
\hline
\end{tabular}

* Spectra recorded as KBr pellets; b: broad; w: weak; s: sharp; m:medium 
characterized by a strong band at $1656-1654 \mathrm{~cm}^{-1}$ due to $v(\mathrm{C}=\mathrm{N})$ and a weak broad band at $3046-3026 \mathrm{~cm}^{-1}$ due to $\mathrm{H}$-bonded $\mathrm{N}^{+}-\mathrm{H} \ldots \mathrm{O}^{-}$vibration of the protonated imine. ${ }^{23}$ Thus, the above evidence supports for none involvement of bonding between lanthanide and the imine nitrogen; instead the ligand coordinates to the $\mathrm{Ln}^{\mathrm{III}}$ ions via the negatively charged phenolic oxygen.

The $\mathrm{Ln}^{\mathrm{III}}$ complexes also exhibit three additional characteristic bands of the vibrational modes of the coordinated nitrate groups ( $C_{2 v}$ symmetry) at $1472-1467$, 1294-1288, and 794-791 $\mathrm{cm}^{-1} .{ }^{24}$ Besides, the mono- and bidentate chelating nitrates in the complexes may be distinguished on the basis of the profile and separation of the modes associated with asymmetric nitrate vibrations. Accordingly, a bidentate coordinated nitrate is indicated by the magnitude of splitting $\left(181-175 \mathrm{~cm}^{-1}\right)$ at higher energies. ${ }^{24,25}$ The non-coordinated nitrate present in the ionization sphere is supported by additional bands at $1386-1372 \mathrm{~cm}^{-1}$.

\section{4. ${ }^{1} \mathrm{H}$ and ${ }^{13} \mathrm{C}$ NMR Spectral Studies}

A comparison of ${ }^{1} \mathrm{H}$ NMR spectral data of the ligand with that of the $\mathrm{La}^{\mathrm{III}}$ complex shows the phenolic $-\mathrm{OH}$ signal $(\delta, 13.80)$ that appear in the ligand, disappears later upon complexation. Further, the ${ }^{1} \mathrm{H}$ NMR spectral data imply the shifting of phenolic protons to the two uncoordinated imino nitrogen atoms, which give zwitterionic structure $\left(=\mathrm{N}^{+}-\mathrm{H} \cdots \mathrm{O}^{-}\right)$by intramolecularly hydrogen-bonding to the metal-bound phenolate oxygen atoms; as such is designated as $\mathrm{LH}_{2} \cdot{ }^{26}$ Besides, the $\mathrm{La}{ }^{\mathrm{III}}$ complex $(\delta, 8.36)$ shows a signal corresponding to the imine hydrogen, $\mathrm{CH}=\mathrm{N}$, that got broadened when compared with that of the ligand $(\delta, 8.32)$. Further, the $\mathrm{La}^{\mathrm{III}}$ complex shows a new signal, characteristic of $-\mathrm{N}^{+} \mathrm{H}$ resonance, at $9.27 \delta$ while such a signal is absent in the ligand. The results are in accordance with similar observations made by Binnemans et al. ${ }^{27}$ on metallomesogens, $\left[\mathrm{Ln}(\mathrm{LH})_{3}\left(\mathrm{NO}_{3}\right)_{3}\right]$, where $\mathrm{LH}$

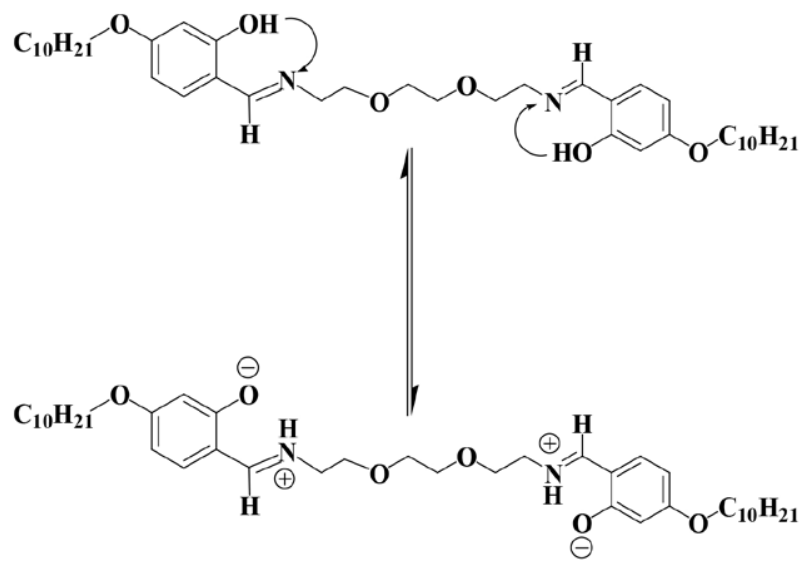

Scheme 2. Depiction of migration of phenolic protons to imine nitrogens of the ligand, $\mathrm{H}_{2} \mathrm{~L}$, during the formation of zwitter ion.
$=4$-alkoxy-N-alkyl-2-hydroxy benzaldimine. Thus, the metal complex has its Schiff base ligand existing in a zwitterionic form, with the phenolic oxygen deprotonated and the imine nitrogen protonated (Scheme 2), as supported evidently by IR and NMR spectral data.

The ${ }^{13} \mathrm{C}\left\{{ }^{1} \mathrm{H}\right\}$ NMR spectral data show a significant shift of the $-\mathrm{NCH}$ signal $\left(\delta, 165.39\right.$ in case of $\mathrm{H}_{2} \mathrm{~L}$ and $\delta$, 166.07 in the $\mathrm{La}^{\mathrm{III}}$ complex) implying the two phenolate oxygen atoms of $\mathrm{H}_{2} \mathrm{~L}$ bonded to $\mathrm{La}^{\text {III }}$ in the zwitterionic form. The carbons directly attached to the phenolate group showed similar shifts while those for the other carbon signals were of lower magnitude.

\section{5. Magnetic and Electronic Spectral Studies}

The $\mu_{\text {eff }}$ values (at room temperature) of all the $\mathrm{Ln}^{\mathrm{III}}$ complexes (Table 1) under the present study have been found to be higher than the reported van Vleck values. These abnormal $\mu_{\text {eff }}$ values, attributed to metal-metal interactions, are in good agreement with similar complexes reported in literatures. ${ }^{28-30}$

The electronic spectra of only the $\mathrm{Pr}^{\mathrm{III}}, \mathrm{Nd}^{\mathrm{III}}, \mathrm{Sm}^{\mathrm{III}}$, and Dy ${ }^{\mathrm{III}}$ complexes (Table 3) were recorded in qualitative solution state from 200 to $1100 \mathrm{~nm}$, in view of their ability to show hypersensitive bands. The considerable red shifts in the $\lambda_{\max }$ values of the above complexes compared to those of the corresponding aqua ions, ${ }^{31}$ are attributed to

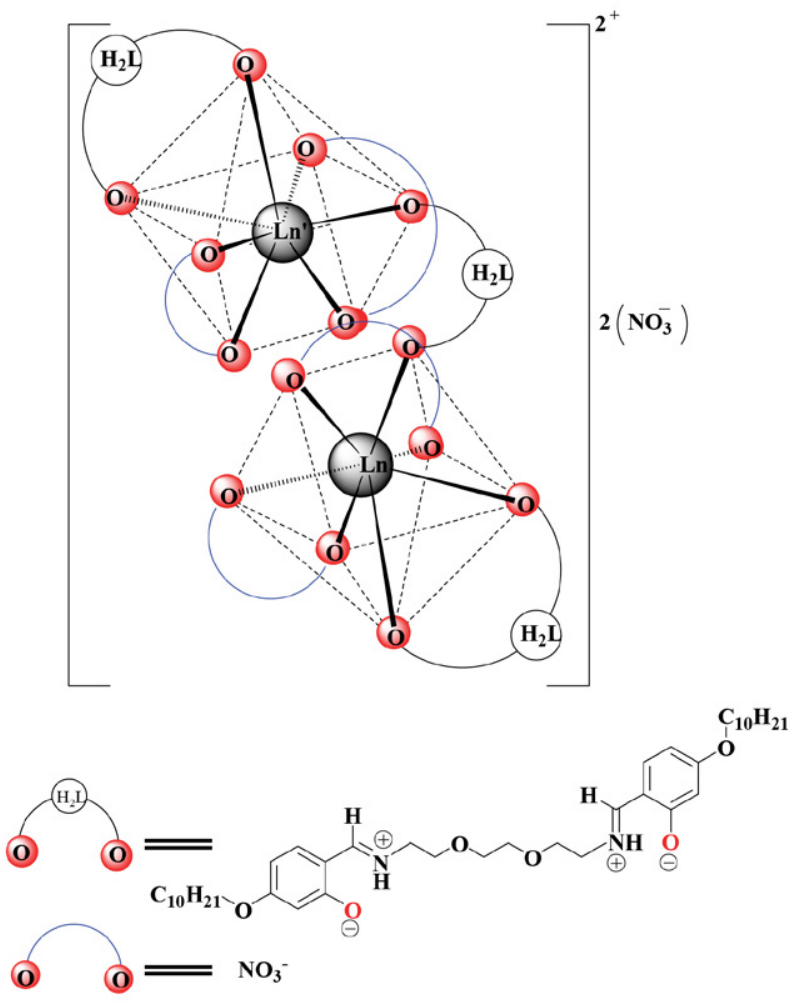

Figure 1. Proposed Polyhedron (Mono-capped Octahedron) for $\left[\mathrm{Ln}_{2}\left(\mathrm{LH}_{2}\right)_{3}\left(\mathrm{NO}_{3) 4}\right]\left(\mathrm{NO}_{3}\right)_{2}: \mathrm{Ln}=\mathrm{La}, \mathrm{Pr}, \mathrm{Nd}, \mathrm{Sm}, \mathrm{Eu}, \mathrm{Gd}, \mathrm{Tb}, \mathrm{Dy}\right.$ and Ho 
Table 3. Electronic spectral data of the selected metal complexes of $\mathrm{H}_{2} \mathrm{~L}$.

\begin{tabular}{|c|c|c|c|c|c|}
\hline \multicolumn{3}{|c|}{$\operatorname{Pr}($ III) } & \multicolumn{3}{|c|}{ Nd(III) } \\
\hline $\begin{array}{l}\text { Transitions/ } \\
\text { Bonding } \\
\text { parameters }\end{array}$ & $\begin{array}{c}\lambda_{\max }\left(\mathrm{cm}^{-1}\right) \\
\text { aq. ion }\end{array}$ & $\begin{array}{c}\lambda_{\max } \\
\left(\mathrm{cm}^{-1}\right) \\
\text { complex }\end{array}$ & $\begin{array}{l}\text { Transitions/ } \\
\text { Bonding } \\
\text { parameters }\end{array}$ & $\begin{array}{c}\lambda_{\max }\left(\mathrm{cm}^{-1}\right) \\
\text { aq. ion }\end{array}$ & $\begin{array}{c}\lambda_{\max } \\
\left(\mathrm{cm}^{-1}\right) \\
\text { complex }\end{array}$ \\
\hline${ }^{1} G_{4} \leftarrow{ }^{3} H_{4}$ & 9900 & 9800 & ${ }^{4} \boldsymbol{F}_{3 / 2} \leftarrow{ }^{4} \boldsymbol{I}_{9 / 2}$ & 11,450 & 11,435 \\
\hline${ }^{1} D_{2}^{*} \leftarrow$ & $16850^{\star}$ & 16,840 & ${ }^{4} F_{5 / 2} \leftarrow$ & 12,500 & 12,484 \\
\hline \multirow[t]{5}{*}{${ }^{3} P_{0} \leftarrow$} & 20800 & 20,760 & ${ }^{4} S_{3 / 2},{ }^{4} F_{7 / 2} \leftarrow$ & 13,500 & 13,430 \\
\hline & & & ${ }^{4} F_{9 / 2} \leftarrow$ & 14,800 & 14,694 \\
\hline & & & ${ }^{2} H_{11 / 2} \leftarrow$ & 15,900 & 15,850 \\
\hline & & & ${ }^{2} G_{7 / 2}{ }^{\star} \leftarrow$ & $17,400^{*}$ & 17,196 \\
\hline & & & ${ }^{4} G_{7 / 2} \leftarrow$ & 19,100 & 19,015 \\
\hline$\beta$ & & 0.993 & & & 0.995 \\
\hline$b^{1 / 2}$ & & 0.059 & & & 0.050 \\
\hline$\% \delta$ & & 0.705 & & & 0.503 \\
\hline$\eta$ & & 0.003 & & & 0.002 \\
\hline \multicolumn{3}{|c|}{$\operatorname{Sm}(I I I)$} & \multicolumn{3}{|c|}{ Dy(III) } \\
\hline${ }^{6} F_{9 / 2} \leftarrow{ }^{6} H_{5 / 2}$ & 9200 & 9174 & ${ }^{6} H_{7 / 2} \leftarrow{ }^{6} H_{15 / 2}$ & 9100 & - \\
\hline${ }^{6} F_{11 / 2} \leftarrow$ & 10,500 & 10,352 & ${ }^{6} F_{9 / 2} \leftarrow$ & & \\
\hline${ }^{4} G_{5 / 2} \leftarrow$ & 17,900 & - & ${ }^{6} \mathrm{H}_{5 / 2} \leftarrow$ & 10,200 & 10,156 \\
\hline${ }^{6} P_{7 / 2}{ }^{*} \leftarrow$ & $26,750^{*}$ & 26,197 & ${ }^{6} F_{7 / 2} \leftarrow$ & 11,000 & 10,952 \\
\hline \multirow[t]{2}{*}{${ }^{4} D_{7 / 2}$} & 29,100 & 29,185 & ${ }^{6} F_{5 / 2} \leftarrow$ & 12,400 & 12,392 \\
\hline & & & ${ }^{4} \boldsymbol{F}_{7 / 2} \leftarrow$ & 25,800 & 25,828 \\
\hline$\beta$ & & 0.991 & & & 0.998 \\
\hline$b^{1 / 2}$ & & 0.067 & & & 0.032 \\
\hline$\% \delta$ & & 0.908 & & & 0.200 \\
\hline$\eta$ & & 0.004 & & & 0.001 \\
\hline
\end{tabular}

${ }^{*}$ Hypersensitive band.

the Nephelauxetic effect, ${ }^{32}$ which is regarded as a measure of covalency of the bonding between the metal ions and the ligands. Various bonding parameters (Table 3), viz., Nephelauxetic ratio $(\beta)$, bonding parameter $\left(b^{1 / 2}\right)$, Sinha's parameter $(\% \delta)$, and covalency angular overlap parameter $(\eta)$, calculated by the procedures as reported, ${ }^{33}$ suggest a weak covalent nature of the metal-ligand bonds.

Based on the above spectral evidences, the seven-coordinate geometry, possibly in a distorted mono-capped octahedron (Figure 1) may be proposed to all the present complexes in which the mesogenic Schiff base, $N, N^{\prime}$-di-(4-decyloxysalicylidene)-1',8'-diamino-3',6'-dioxaoctane $\left(\mathrm{H}_{2} \mathrm{~L}\right), 2$, coordinates to the $\mathrm{Ln}^{\mathrm{III}}$ ions in a neutral bidentate fashion.

\section{6 Optical and Thermal Studies}

The DSC (recorded in the second heating and cooling cycle with heating rate of $10^{\circ} \mathrm{C} / \mathrm{min}$ ) and POM (heating and cooling rates of $2{ }^{\circ} \mathrm{C} / \mathrm{min}$ ) were employed to study liquid crystalline (mesogenic) properties of the ligand and those of the $\mathrm{Ln}^{\mathrm{III}}$ complexes. The corresponding transition temperatures, enthalpy, and entropy changes are given in Table 4.
Table 4. Thermodynamic data (transition temp., enthalpy and entropy changes).

\begin{tabular}{|c|c|c|c|c|}
\hline Ligand & Transition $^{a}$ & $T^{b}\left({ }^{\circ} \mathrm{C}\right)$ & $\begin{array}{c}\Delta H^{b} \\
\left(\mathrm{~kJ} \mathrm{~mol}^{-1}\right)\end{array}$ & $\begin{array}{c}\Delta S \\
\left(\mathrm{~J} \mathrm{~mol}^{-1} \mathrm{~K}^{-1}\right)\end{array}$ \\
\hline \multirow[t]{7}{*}{$\mathrm{H}_{2} \mathrm{~L}$} & $\mathrm{Cr}-\mathrm{SmX}$ & 91.84 & 10.62 & 29.11 \\
\hline & $\mathrm{SmX}-\mathrm{SmA}$ & 116.96 & 10.52 & 26.98 \\
\hline & $\mathrm{SmA}-\mathrm{N}$ & 131.93 & 16.52 & 40.80 \\
\hline & $\mathrm{N}-\mathrm{I}$ & 162.85 & 6.09 & 13.97 \\
\hline & $\mathrm{I}-\mathrm{N}$ & 148.53 & 2.39 & 5.67 \\
\hline & $\mathrm{N}-\mathrm{SmX}$ & 141.73 & 1.12 & 2.70 \\
\hline & $\mathrm{SmX}-\mathrm{Cr}$ & 89.96 & 20.20 & 55.65 \\
\hline
\end{tabular}

${ }^{a}$ Cr: Crystal; SmX: Smectic-X; SmA: Smectic-A; N: Nematic; I-Isotropic liquid ${ }^{b}$ Data as obtained from the DSC cycle

The POM study revealed optical textures of the $\mathrm{H}_{2} \mathrm{~L}$ (Figure 2) implying smectic-X $(\operatorname{SmX})$, smectic-A $(\operatorname{SmA})$ and nematic $(N)$ mesophases while none of the $\mathrm{Ln}^{\mathrm{III}}$ complexes reported here exhibited mesomorphism. The non-mesomorphism in the $\mathrm{Ln}^{\mathrm{III}}$ complexes may be attributed to very high thermal energy required to melt completely the alkoxy chains of the complexes. Under the 

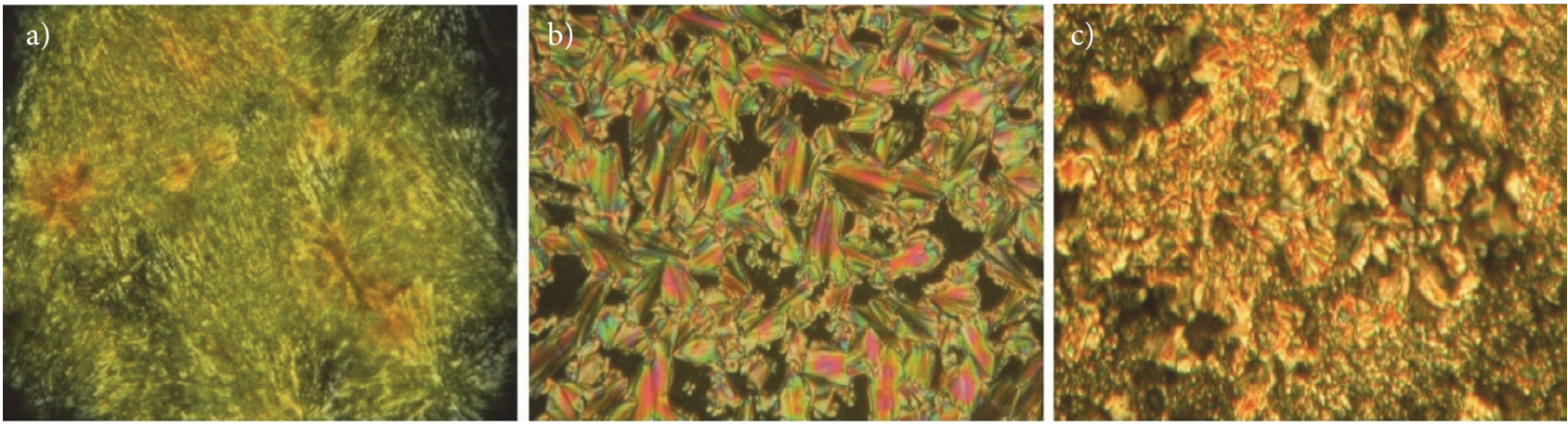

Figure 2. Optical textures of Schiff base $\left(\mathrm{H}_{2} \mathrm{~L}\right)$ : (a) Smectic-X $(\operatorname{SmX})$, (b) Smectic-A $(\operatorname{SmA})$ and (c) Nematic $(N)$

given situation of high energy level, the layered structure in the complexes breaks down prior to the alkoxy chains, losing thereby the mesogenic properties of the materials. ${ }^{27}$

\section{7. Luminescence Studies}

The $\mathrm{H}_{2} \mathrm{~L}$ shows fluorescence (Figure 3a) with an emission band at $410 \mathrm{~nm}$ due to intra-ligand transition
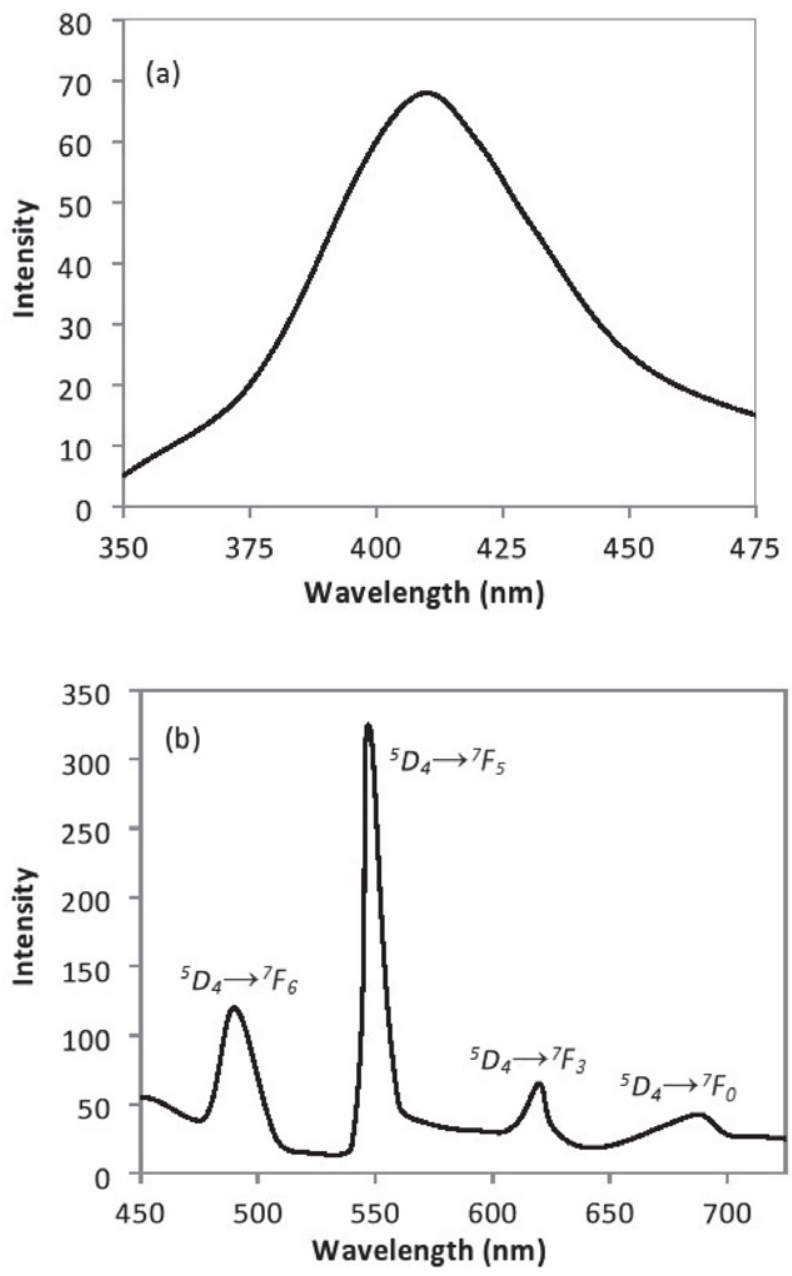

Figure 3. The fluorescence spectra of (a) $\mathrm{H}_{2} \mathrm{~L}$ and (b) $\mathrm{Tb}^{\mathrm{III}}$ complex. and the $\mathrm{Tb}^{\mathrm{III}}$ complex (Figure $3 \mathrm{~b}$ ) with four typical metal-centered emission bands at $490 \mathrm{~nm}\left({ }^{5} D_{4} \rightarrow{ }^{7} F_{6}\right), 547 \mathrm{~nm}$ $\left({ }^{5} D_{4} \rightarrow{ }^{7} F_{5}\right), 620 \mathrm{~nm}\left({ }^{5} D_{4} \rightarrow{ }^{7} F_{3}\right)$, and $685 \mathrm{~nm}\left({ }^{5} D_{4} \rightarrow{ }^{7} F_{0}\right)$ respectively. ${ }^{34}$

Under the same experimental conditions, the observed fluorescence intensities of the $\mathrm{Sm}^{\mathrm{III}}$, Eu ${ }^{\mathrm{III}}$ and Dy ${ }^{\mathrm{III}}$ complexes were observed to be weak (spectra not shown) and their emission spectra also did not show any bands characteristic of metal-centered emission. Thus, it may be inferred that the $\mathrm{H}_{2} \mathrm{~L}$ is likely to be a suitable organic chelator to absorb energy and transfer the same to $\mathrm{Tb}^{\mathrm{III}}$ ion, implying the wellknown intramolecular energy transfer mechanism exhibited by lanthanide Schiff base complexes. ${ }^{35}$

\section{Conclusion}

The mesogenic (SmX, SmA and N) Schiff base, $N, N^{\prime}$-di-(4-decyloxysalicylidene)-1',8'-diamino-3',6'-dioxaoctane $\left(\mathrm{H}_{2} \mathrm{~L}\right)$, coordinates to $\mathrm{Ln}^{\mathrm{III}}$ ions $(\mathrm{Ln}=\mathrm{La}, \mathrm{Pr}, \mathrm{Nd}$, $\mathrm{Sm}, \mathrm{Eu}, \mathrm{Gd}, \mathrm{Tb}, \mathrm{Dy}$, and $\mathrm{Ho}$ ) as a neutral bidentate species to yield seven-coordinate non-mesogenic complexes of the formula, $\left[\mathrm{Ln}_{2}\left(\mathrm{LH}_{2}\right)_{3}\left(\mathrm{NO}_{3}\right)_{4}\right]\left(\mathrm{NO}_{3}\right)_{2}$, the polyhedron being possibly distorted mono-capped octahedron. The neutral bidentate $\mathrm{H}_{2} \mathrm{~L}$ coordinates to $\mathrm{Ln}^{\mathrm{III}}$ in a zwitterionic form through two phenolate oxygen atoms along with bonding of nitrato groups in similar bidentate fashion. Luminescence of the $\mathrm{H}_{2} \mathrm{~L}$ and $\mathrm{Tb}^{\mathrm{III}}$ complex arises due to intra-ligand and metal-centered emissions respectively.

\section{Acknowledgements}

One of the authors, P.R. Shakya gratefully acknowledges the University Grants Commission (UGC), Kathmandu, Nepal, for research fellowship.

\section{References}

1. D. Parker, R. S. Dickins, H. Puschmann, C. Crossland, J. A. K. Howard, Chem. Rev. 2002, 102, 1977-2010;

DOI: $10.1021 / \mathrm{cr} 010452+$ 
2. C. Piguet, J. C. G. Bunzli, B. Donnio, D. Guillon, Chem. Commun. 2006, 3755-3768; DOI: 10.1039/B605737C

3. L. J. Charbonniere, R. Ziessel, M. Montalti, L. Prodi, N. Zaccheroni, C. Boehme, G. Wipff, J. Am. Chem. Soc. 2002, 124, 7779-7788; DOI: 10.1021/ja0200847

4. H. J. Zhang, R. H. Gou, L. Yan, R. D. Yang, Spectrochim. Acta Part A 2007, 66, 289-294; DOI: 10.1016/j.saa.2006.02.054

5. M. Tsiouri, N. Hadjiliadis, T. Arslan, B. M. Kariuki, J. C. Plakatouras, Inorg. Chem. Commun. 2006, 9, 429-432; DOI:10.1016/j.inoche.2005.12.018

6. K. Lodewyckx, R. V. Deun, K. Binnemans, Mater. Sci. Eng. C 2001, 18, 217-221; DOI:10.1016/S0928-4931(01)00361-7

7. A. M. Giroud-Godquin, P. M. Maitlis, Angew. Chem. 1991, 30, 375-402; DOI:10.1002/anie.199103751

8. D. W. Bruce, In Inorganic Materials, 2nd ed.; Bruce, D. W., O'Hare, D., Eds.; Wiley: Chichester, Chapter 8, 1996, pp 405-490.

9. K. Binnemans, K. Lodewyckx, Angew. Chem. 2001, 13, 248244; DOI:10.1002/1521-3773(20010105)40:1<242::AIDANIE242>3.0.CO;2-O

10. C. Piechocki, J. Simon, J. J. Andre, D. Guillon, P. Petit, A. Skoulios, P. Weber, Chem. Phys. Lett. 1985, 122, 124-128; DOI:10.1016/0009-2614(85)85490-7

11. Y. G. Galyametdinov, G. I. Ivanova, I. V. Ovchinnikov, Bull. Acad. Sci. USSR, Div. Chem. Sci., 1991, 40, 1109-1115. https://doi.org/10.1007/BF00961392

12. P. R. Shakya, A. K. Singh, T. R. Rao, Spectrochim. Acta A 2011 , 79, 1654-1659; DOI:10.1016/j.saa.2011.05.030

13. P. R. Shakya, A. K. Singh, T. R. Rao, Mater. Sci. Eng. C 2012, 32, 1906-1911; DOI:10.1016/j.msec.2012.05.039

14. P. R. Shakya, A. K. Singh, T. R. Rao, J. Coord. Chem. 2012, 65, 3519-3529; DOI:10.1080/00958972.2012.719225

15. P. R. Shakya, A. K. Singh, T. R. Rao, Synth. Rect. Inorg. Met. Org. Chem. 2014, 44, 739-747;

DOI:10.1080/15533174.2013.790056

16. A. K. Singh, S. Kumari, P. R. Shakya, T. R. Rao, Mater. Sci. Eng. C 2011, 31, 1111-1114; DOI:10.1016/j.msec.2011.04.006

17. P. K. Shrestha, P. R. Shakya, J. Nepal Chem. Soc. 2020, 41, 16-25; DOI:10.3126/jncs.v41i1.30509

18. A. Weisberger, F. S. Praskver, Organic Solvents, International Publishers Inc., New York, 1956, p. 1263.

19. W. J. Geary, Coord. Chem. Rev. 1971, 7, 81-122; DOI:10.1016/S0010-8545(00)80009-0

20. R. M. Silverstein, F. X. Webster, Spectrometric Identification of Organic Compounds, 6th Ed., John Wiley \& Sons Inc., New York, 2002.

21. N. B. Colthup, L. H. Daly, S. E. Wiberley, Introduction to Infrared and Raman Spectroscopy, 3rd Ed., Academic Press, New York, 1990.

22. K. Binnemans, D. W. Bruce, S. R. Collinson, R. Van Deun, Y. G. Galyametdinov, F. Martin, Philos. Trans. R. Soc. Lond., Ser. A 1999, 357, 3063-3077; DOI:10.1098/rsta.1999.0481

23. K. Binnemans, R. van Deun, Christiane G. Walrand, W. Haase, D. W. Bruce, L. Malykhina, Y. G. Galyametdinov, Mater. Sci. Eng. C 2001, 18, 247-254; DOI:10.1016/S09284931(01)00369-1
24. B. Keshavan, P. G. Chandrashekara, N. M. Made Gowda, J. Mol. Struct. 2000, 553, 193-197;

DOI:10.1016/S0022-2860(00)00551-2

25. J. Nawrocka, V. Patroniak, J. Alloys Compd. 2004, 380, 159162; DOI:10.1016/j.jallcom.2004.03.079

26. P. Bag, U. Flörke, K. Nag, Dalton Trans. 2006, 26, 3236-3248; DOI:10.1039/B516306D

27. K. Binnemans, Y. G. Galyametdinov, R. van Deun, D. W. Bruce, S. R. Collison, A. P. Polishchuk, I. Bikechantaev, W. Hasse, A. V. Prosvirin, L. Tinchurina, I. Litvinov, A. Gubajdullin, A. Rakhamatullin, K. Uytterhoeven, L. VanMeervelt, J. Am. Chem. Soc. 2000, 122, 4335-4344; DOI:10.1021/ja993351q

28. W. Plass, G. Fries, Z. Anorg, Allg. Chem. 1997, 623, 12051207; DOI:10.1002/zaac.19976230804

29. J. P. Costes, F. Dahan, A. Dupuis, S. Lagrave, J. P. Laurent, Inorg. Chem. 1998, 37, 153-155; DOI:10.1021/ic9712481

30. J. P. Costes, A. Dupuis, J. P. Laurent, Inorg. Chim. Acta 1998, 268, 125-130; DOI:10.1016/S0020-1693(97)05628-4

31. R. Reisfeld, C.K. Jorgensen, Lasers and Excited States of Rare Earths, SpringerVerlag, Berlin, 1977. https://doi.org/10.1007/978-3-642-66696-4

32. W. T. Carnall, P. R. Fields, K. Rajnak, J. Chem. Phys. 1968, 49, 4424-4442; DOI:10.1063/1.1669893

33. T. R. Rao, P. A. Kumar, Synth. Rect. Inrg. Met. Org. Chem. 1995, 25, 1011-1026; DOI:10.1080/15533179508218277

34. T. Gao, P. F. Yan, G. M. Li, G. F. Hou, J. S. Gao, Inorg. Chim. Acta 2008, 361, 2051-2058; DOI:10.1016/j.ica.2007.10.021

35. R. D. Archer, H. Chen, L. C. Thompson, Inorg. Chem. 1998, 37, 2089-2095; DOI:10.1021/ic960244d 


\section{Povzetek}

Sintetizirali smo mezogeno Schiffovo bazo, N,N'-di(4-deciloksisaliciliden)-1',8'-diamino-3',6'-dioksaoktan $\left(\mathrm{H}_{2} \mathrm{~L}\right)$ in serijo homo dvojedrnih lantanoidnih(III) kompleksov tipa $\left[\mathrm{Ln}_{2}\left(\mathrm{LH}_{2}\right)_{3}\left(\mathrm{NO}_{3}\right)_{4}\right]\left(\mathrm{NO}_{3}\right)_{2},(\mathrm{Ln}=\mathrm{La}, \mathrm{Pr}, \mathrm{Nd}, \mathrm{Sm}, \mathrm{Eu}, \mathrm{Gd}, \mathrm{Tb}, \mathrm{Dy}$, in Ho) ter jih okarakterizirali z elementno analizo, masno spektrometrijo, FTIR in NMR spektroskopijo. IR in NMR analizi nakazujeta vezavo nevtralne dvovezne $\mathrm{H}_{2} \mathrm{~L}$ zvrsti preko dveh fenolatnih kisikovih atomov v zwitterionski obliki na $\mathrm{Ln}^{\mathrm{III}}$, kar vodi do kompleksa s koordinacijskim številom sedem - verjetno popačen oktaeder s sedmim donorskim ligandom nad stransko ploskvijo. DSC in polarizacijski optični mikroskop (POM) razkrijeta mezogene lastnosti (smektična $\mathrm{X}$, smektična $\mathrm{A}$ in nematična mezofaze) liganda $\mathrm{v}$ širokem temperaturnem območju, vendar nobenega mezomorfizma pri $\mathrm{Ln}^{\mathrm{III}}$ kompleksih, sintetiziranih pri tej študiji. Študij luminescence pokaže emisije pri $\mathrm{H}_{2} \mathrm{~L}_{\text {in }} \mathrm{Tb}^{\mathrm{III}}$ kompleksih. 